\title{
Penelitian
}

\section{PENGARUH PROGRESSIVE MUSCLE RELAXATION SEBAGAI PENERAPAN PALLIATIF CARE TERHADAP NYERI DAN KECEMASAN
PASIEN KANKER SERVIKS}

\author{
${ }^{1}$ Eka Nadya Rahmania, ${ }^{2}$ Jum Natosba, ${ }^{3}$ Karolin Adhisty \\ 1,2,3Program Studi IImu Keperawatan Fakultas Kedokteran \\ Universitas Sriwijaya \\ Jalan Lintas Palembang-Prabumulih Km.32 Zona F Gedung Abdul \\ Muthalib, \\ Indralaya, Kabupaten Ogan Ilir 30662 \\ Email : ekanadyar@gmail.com
}

\begin{abstract}
ABSTRAK
Kanker serviks merupakan masalah global terkait penyakit tidak menular yang dapat menyebabkan kesakitan hingga kematian pada wanita. Penderita kanker serviks umumnya mengalami keluhan nyeri dan kecemasan yang dapat mempengaruhi kualitas hidup. Salah satu bentuk penerapan perawatan paliatif dengan kualitas hidup sebagai prioritas pengobatan untuk pasien dengan penyakit kronik seperti kanker serviks ialah Progressive Muscle Relaxation. Tujuan penelitian untuk mengetahui pengaruh Progressive Muscle Relaxation terhadap nyeri dan kecemasan pasien kanker serviks. Jenis penelitian ini ialah penelitian kuantitatif dengan pra eksperimental dalam klasifikasi one group pretest and posttest design. Sampel penelitian berjumlah 16 orang responden kanker serviks yang diambil dengan teknik purposive sampling. Hasil analisis skala nyeri dan skor kecemasan menggunakan uji paired t-test dan uji alternatif wilcoxon menunjukkan bahwa Progressive Muscle Relaxation dapat menurunkan skala nyeri dan skor kecemasan dengan $p$-value $=0,000$. Progressive Muscle Relaxation dapat merangsang sistem saraf parasimpatis yang akan mengontrol aktivitas dan mempengaruhi neurotransmitter yang mengantarkan ke sistem saraf pusat. Stimulus tersebut dapat memacu pelepasan hormon endorphin yang menimbulkan ketegangan otot berkurang sehingga tubuh menjadi relaks dan energi positif akan muncul. Energi tersebut akan menghambat jalur ujung-ujung saraf yang menimbulkan nyeri dan kecemasan sehingga tidak dapat diinterpretasikan oleh tubuh. Mekanisme tersebut dapat mengatasi keluhan nyeri dan kecemasan pasien kanker serviks. Progressive Muscle Relaxation dapat dijadikan sebagai intervensi mandiri khususnya perawatan paliatif bagi pasien kanker serviks guna beradaptasi dengan keluhan nyeri dan kecemasan.
\end{abstract}

Kata kunci : Progressive Muscle Relaxation, Nyeri, Kecemasan, Kanker Serviks

\begin{abstract}
Cervical cancer is a global problem related to non infect diseases that cause illness until dying to women. Cervical cancer's patient generally fell pain and anxiety that can affect to the quality of life. One of palliative care with quality of life as a priority treatment for patients with chronic diseases such as cervical cancer is Progressive Muscle Relaxation. This study aimed to analysis the effect of Progressive Muscle Relaxation on the pain and anxiety of cervical cancer's patient. This study design was quantitatif research with pra experimental in one group pretest and posttest design classification. There were 16 respondents of cervical cancer's patient as sample of research, which was taken by purposive sampling technique. Data was analyzed by using paired t-test for pain scale
\end{abstract}


and wilcoxon test for anixety score, result of the study showed that Progressive Muscle Relaxation can decrease pain scale and anxiety score with $p$-value $=0,000$. Progressive Muscle Relaxation is stimulate the parasympathetic nervous system with control the activity and affect the neurotransmitters which delivered to the central nervous system. Stimulation can release of endorphin which causes muscle tension to be reduced so the body becomes relax and positive's energy will be emerge. This energy will inhibit the nervous system that cause pain and anxiety so it can't be interpreted by the body. This mechanism can resolve pain and anxiety of cervical cancer's patient. Progressive Muscle Relaxation can be used as an independent intervention, especially palliative care for cervical cancer's patients to adapt pain and anxiety.

Keyword : Progressive Muscle Relaxation, Pain, Anxiety, Cervical Cancer

\section{PENDAHULUAN}

Kanker serviks merupakan kanker pada wanita yang menyerang bagian leher rahim yang disebabkan oleh virus Human Papilloma Virus (HPV) yang diperkuat keberadaannya dengan faktor risiko seperti berganti-ganti pasangan seksual $>4$ orang, penyakit menular seksual, berhubungan seks pada usia $<20$ tahun, pengguna immunosuppressive pada penderita HIV, dan bahan karsinogen yang dijumpai pada wanita perokok (Aziz, Andrijono, \& Saifuddin, 2006). Data peserta Badan Penyelenggara Jaminan Sosial (BPJS) Kesehatan Nasional tahun 2016, jumlah kasus kanker serviks di pelayanan Rawat Jalan Tingkat Lanjutan (RJTL) mencapai 12.820 kasus sedangkan di Rawat Inap Tingkat Lanjutan (RITL) tercatat ada 6.938 kasus. Kasus kanker serviks menempati urutan pertama di Provinsi Sumatera Selatan pada tahun 2015 sebesar 1.047 penderita. Data dari Rumah Sakit Umum Pusat (RSUP) dr.Mohammad Hoesin Palembang yang merupakan rumah sakit rujukan nasional di Provinsi Sumatera Selatan didapatkan bahwa pasien kanker serviks yang menjalani rawat inap tahun 2018 mengalami peningkatan selama 3 bulan terakhir yaitu 25 orang pada Bulan Januari, 30 orang pada Bulan Februari, dan 39 orang pada Bulan Maret. Kejadian tersebut menandakan bahwa semakin banyak pasien kanker serviks yang memerluhkan perawatan sejak dini.

Nyeri merupakan salah satu gejala kanker yang paling sering menjadi beban berat bagi pasien selama sakit
(Shute, 2013). Nyeri kanker serviks dirasakan pada daerah panggul atau dimulai dari ekstremitas bagian bawah dari daerah lumbal, dapat bervariasi, dan semakin progresif pada stadium lanjut (Wulandari, Effendy, \& Nisman, 2017). Nyeri dan kecemasan merupakan dua gejala pada penderita kanker serviks yang memiliki hubungan saling berkaitan. Kecemasan pada penderita kanker serviks muncul akibat perasaan yang tidak pasti akan prognosa penyakit, keluhan nyeri yang dirasakan, pemeriksaan diagnostik yang dilakukan, dan pengobatan yang dijalani terhadap pemulihan kondisi terutama pada pasien stadium lanjut (Wulandari, Effendy, \& Nisman, 2017).

Intervensi yang diberikan pada pasien kanker serviks dapat berupa terapi farmakologi dan non farmakologi. Terapi farmakologis berupa analgesik yang dapat menimbulkan efek samping lain dan memperparah kondisi apabila diberikan terus-menerus (Maryani, 2009). Pengobatan terhadap keluhan penderita kanker serviks juga dapat dilakukan dengan terapi komplementer. Salah satu terapi komplementer yaitu Progressive Muscle Relaxation (PMR) yang menggabungkan latihan nafas dalam, serangkaian seri kontraksi serta relaksasi otot tertentu, dan distraksi. PMR merupakan salah satu dari teknik relaksasi yang paling mudah dilakukan, memiliki gerakan sederhana, telah digunakan secara luas, dan dapat meningkatkan kemandirian pasien dalam mengatasi masalah kesehatan (Syarif \& Putra, 2014). PMR dilakukan dengan cara menegangkan otot secara sementara, kemudian kembali 
diregangkan dimulai dari kepala sampai kaki secara bertahap (Casey \& Benson, 2012). Teknik relaksasi ini dapat menimbulkan keselarasan tubuh dan pikiran yang diyakini memfasilitasi penyembuhan fisik dan psikologis (LeMone \& Burke, 2008).

PMR merupakan salah satu bentuk penerapan perawatan paliatif untuk pasien kanker serviks. Menurut KEPMENKES RI No.812 Tahun 2007, tujuan perawatan paliatif ialah memperbaiki kualitas hidup pasien dan keluarga dalam menghadapi masalah yang berhubungan dengan penyakit terminal dan kronik dengan pencegahan melalui identifikasi dini dan penilaian yang tertib serta penanganan nyeri dan masalah-masalah lain meliputi fisik, psikososial dan spiritual. Tujuan dari penelitian ini ialah untuk mengetahui pengaruh Progressive Muscle Relaxation terhadap nyeri dan kecemasan pasien kanker serviks di RSUP dr.Mohammad Hoesin Palembang.

\section{METODE}

Penelitian ini merupakan penelitian kuantitatif dengan pra eksperimental dalam klasifikasi one group pretest and posttest design. Sampel penelitian berjumlah 16 orang responden kanker serviks yang diambil dengan teknik purposive sampling. Penelitian ini dilakukan pada bulan Maret-April 2018 di Ruang Rambang 2.2 Instalasi Rawat Inap G RSUP dr.Mohammad Hoesin Palembang. Pemberian latihan PMR dilakukan secara rutin sebanyak 2 kali sehari selama 25-30 menit dalam waktu 5 hari.

Instrumen penelitian ini terdiri atas lembar screening awal responden, lembar karakteristik responden, lembar observasi pengukuran nyeri dan kecemasan, alat pengukuran nyeri menggunakan Visual Analog Scale (VAS), alat pengukuran kecemasan menggunakan kuesioner Zung SelfRating Anxiety Scale (SAS/SRAS), dan panduan pelaksanaan PMR. Analisa data penelitian terdiri atas dua jenis, yaitu analisis univariat dan analisis bivariat yang menggunakan uji Shapiro Wilk sebagai uji normalitas data dan didapatkan bahwa data pengukuran skala nyeri terkategori normal $(p>0,05)$ sehingga dilanjutkan dengan menggunakan uji paired t-test sedangkan data pengukuran skor kecemasan terkategori tidak normal $(p<0,05)$ sehingga dilanjutkan dengan menggunakan uji alternatif Wilcoxon. Peneliti telah mengajukan penelitian ini ke komite etik penelitian untuk mendapatkan persetujuan etik (ethical clearence) dalam melakukan penelitian.

\section{HASIL}

Tabel 1. Karakteristik Responden

\begin{tabular}{|c|c|c|}
\hline Variabel & Frekuensi (n) & Presentase (\%) \\
\hline \multicolumn{3}{|l|}{ Usia } \\
\hline 35 Tahun & 1 & 6,2 \\
\hline 36 Tahun & 1 & 6,2 \\
\hline 39 Tahun & 2 & 12,5 \\
\hline 42 Tahun & 1 & 6,2 \\
\hline 43 Tahun & 1 & 6,2 \\
\hline 47 Tahun & 3 & 18,8 \\
\hline 48 Tahun & 1 & 6,2 \\
\hline 49 Tahun & 1 & 6,2 \\
\hline 51 Tahun & 2 & 12,5 \\
\hline 52 Tahun & 1 & 6,2 \\
\hline 54 Tahun & 2 & 12,5 \\
\hline Total & 16 & $100 \%$ \\
\hline \multicolumn{3}{|l|}{ Stadium } \\
\hline II A & 1 & 6,2 \\
\hline
\end{tabular}


E - ISSN : $2722-127 X$

$P$ - ISSN : $2338-4700$

\begin{tabular}{|c|c|c|}
\hline $\begin{array}{l}\text { II B } \\
\text { III B }\end{array}$ & $\begin{array}{c}4 \\
11 \\
16\end{array}$ & $\begin{array}{c}25 \\
68,8 \\
100 \%\end{array}$ \\
\hline \multicolumn{3}{|c|}{ Lama menderita kanker } \\
\hline$<1$ Tahun & 10 & 62.5 \\
\hline 1 Tahun & 6 & 37,5 \\
\hline Total & 16 & $100 \%$ \\
\hline \multicolumn{3}{|l|}{ Pendidikan } \\
\hline SD & 12 & 75 \\
\hline SMP & 1 & 6,2 \\
\hline SMA & 3 & 18,8 \\
\hline Total & 16 & $100 \%$ \\
\hline \multicolumn{3}{|l|}{ Pekerjaan } \\
\hline Ibu Rumah Tangga & 7 & 43,8 \\
\hline Pedagang & 6 & 37,5 \\
\hline Petani & 3 & 18,8 \\
\hline Total & 16 & $100 \%$ \\
\hline \multicolumn{3}{|l|}{ Status pernikahan } \\
\hline Menikah & 16 & 100 \\
\hline \multicolumn{3}{|c|}{ Pengobatan yang dijalani } \\
\hline Kemoterapi & 12 & 75 \\
\hline Radioterapi & 4 & 25 \\
\hline Total & 16 & $100 \%$ \\
\hline
\end{tabular}

Tabel 2. Perbedaan Skala Nyeri pada Pasien Kanker Serviks Sebelum dan Setelah diberikan Intervensi PMR dengan menggunakan Uji Paired t-test

\begin{tabular}{|c|c|c|c|c|c|c|}
\hline \multirow{2}{*}{ Variabel } & \multirow{2}{*}{$\mathbf{n}$} & \multirow{2}{*}{ Mean } & \multirow{2}{*}{ SD } & \multirow{2}{*}{$p$-value } & \multicolumn{2}{|c|}{$\begin{array}{c}\text { 95\% Confidence } \\
\text { Interval (Cl) }\end{array}$} \\
\hline & & & & & Lower & Upper \\
\hline $\begin{array}{c}\text { Skala Nyeri Sebelum } \\
\text { Intervensi }\end{array}$ & 16 & 5,75 & 1,528 & & & \\
\hline $\begin{array}{c}\text { Skala Nyeri Setelah } \\
\text { Intervensi }\end{array}$ & 16 & 3,06 & 1,692 & 0,000 & 2.432 & 2.943 \\
\hline
\end{tabular}

Nilai mean skala nyeri sebelum diberikan intervensi lebih tinggi dibandingkan nilai mean skala nyeri setelah diberi intervensi menandakan bahwa terdapat perubahan berupa penurunan rata-rata skala nyeri sehingga dapat disimpulkan adanya perbedaan yang bermakna skala nyeri pasien kanker serviks sebelum dan setelah diberikan intervensi. Skala nyeri pada penelitian ini berada dalam rentang 2,943 sampai 2,432 dengan tingkat kepercayaan penelitian $95 \%$.

Tabel 3. Perbedaan Skor Kecemasan pada Pasien Kanker Serviks Sebelum dan Setelah diberikan Intervensi PMR dengan menggunakan Uji Wilcoxon

\begin{tabular}{cccc}
\hline Variabel & $\mathbf{n}$ & $\begin{array}{c}\text { Median (Minimum- } \\
\text { Maksimum) }\end{array}$ & p-value \\
\hline $\begin{array}{c}\text { Skor Kecemasan Sebelum } \\
\text { Intervensi }\end{array}$ & 16 & $50(63-33)$ & \\
$\begin{array}{c}\text { Skor Kecemasan Setelah } \\
\text { Intervensi }\end{array}$ & 16 & 28(54-23) & \\
\hline
\end{tabular}

Nilai median pada skor kecemasan sebelum diberikan intervensi lebih tinggi dibandingkan skor kecemasan setelah diberikan intervensi, dengan selisih median sebelum dan setelah diberikan intervensi sebesar 22 yang menandakan 
terdapat perubahan berupa penurunan skor kecemasan sehingga dapat disimpulkan adanya perbedaan yang bermakna skor kecemasan pasien

\section{PEMBAHASAN}

Karakteristik responden pada penelitian ini ditinjau berdasarkan usia, stadium kanker, pendidikan terakhir responden, pekerjaan, status pernikahan, lama menderita kanker, dan pengobatan yang akan dijalani. Usia responden pada penelitian ini berkisar 35-54 tahun. Hal ini sejalan dengan penelitian Susilowati dan Sirait (2014) bahwa jumlah wanita penderita kanker serviks terbanyak dalam golongan usia 35-54 tahun. Wanita berusia 35-55 tahun yang masih aktif berhubungan seksual (prevalensi 5-10\%) terkategori rawan mengidap kanker serviks dikarenakan peningkatan usia selalu diiringi dengan penurunan kinerja organorgan dan kekebalan tubuh sehingga menimbulkan tubuh lebih rentan terserang infeksi.

Karakteristik responden juga dilihat dari status pernikahan, didapatkan dalam penelitian ini seluruh responden berstatus menikah. Penelitian Prandana dan Rusda (2013) di RSUP H.Adam Malik Medan sejalan dengan penelitian ini bahwa semua responden kanker serviks sebanyak 367 orang (100\%) berstatus menikah. Responden penelitian ini berada pada tingkatan stadium IIA-IIIB. Penelitian Lasut, Rarung, dan Suparman (2015) sejalan dengan penelitian ini bahwa stadium IIA, IIB, dan IIIB merupakan tiga tingkatan stadium tertinggi di RSUP Prof.DR.R.D.Kandou. Tumor yang telah menyebar ke luar serviks dan melibatkan jaringan di rongga pelvis dapat dijumpai pada stadium lanjut sehingga penderita akan mengetahui diagnosa kanker serviks ketika telah berada di stadium lanjut (Aziz, Andrijono, \& Saifuddin, 2006).

Pendidikan terakhir responden penelitian ini terbanyak pada tingkat Sekolah Dasar (SD) dan paling sedikit pada tingkat Sekolah Menengah (SMP dan SMA). Penelitian ini sejalan dengan kanker serviks sebelum dan setelah diberikan intervensi PMR.

penelitian Prandana dan Rusda (2013) yang menyatakan penderita kanker serviks dengan status pendidikan terbanyak digolongkan dalam tingkat sedang (SMP-SMA). Pendidikan dapat menentukan pengetahuan seseorang mengenai penyakit yang diderita dan tindakan yang akan dilakukan dalam mengatasi keluhan fisik dan psikologis yang dirasakan.

Pekerjaan terbanyak responden penelitian sebagai Ibu Rumah Tangga (IRT) sebanyak 7 orang $(43,8 \%)$. Penelitian dari Lasut, Rarung, dan Suparman (2015) sejalan dengan penelitian ini bahwa ibu yang bekerja sebagai IRT terbanyak menderita kanker serviks yaitu 37 kasus (92,5\%). Individu yang bekerja dapat dengan mudah mengetahui informasi dari luar baik informasi yang berhubungan dengan kebutuhan sehari-hari maupun informasi kesehatan (Susilawati, 2013).

Faktor lain yang mempengaruhi kejadian kanker serviks ialah lama menderita kanker dan pengobatan yang akan dijalani. Responden penelitian yang menderita kanker serviks lebih dari 1 tahun telah menjalani pengobatan kemoterapi sebanyak 6 kali dalam siklus setiap 20 hari dan radioterapi sebanyak 25 kali dalam siklus setiap hari. Keberhasilan pengobatan dan kepatuhan dalam menjalani terapi yang dianjurkan dapat membuat kondisi fisik pasien menjadi stabil serta pasien yang lama menderita suatu penyakit akan mengalami penerimaan terhadap kondisi dan penyakit yang diderita seiring berjalan waktu.

Hasil penelitian ini menunjukkan bahwa $p=0,000$ yang berarti bahwa secara statistik dapat diartikan terdapat perbedaan yang bermakna antara skala nyeri sebelum dan setelah diberikan intervensi PMR. Responden penelitian melaporkan nyeri yang dirasakan terlokalisir di daerah sekitar rahim dan pelvis. Hal tersebut sejalan dengan teori Berek (2012) yang menyatakan nyeri 
kanker serviks biasanya dapat dirasakan di daerah pinggul atau yang terletak di dalam atau di pusat pelvis. Responden penelitian juga melaporkan bahwa nyeri yang dirasakan menyebar ke daerah paha. Nyeri kanker serviks menjalar ke sisi anterior sampai sisi medial dari paha yang dicurigai terjadinya kompresi nervus femoral (Suwiyoga, 2013) sehingga dapat menambah keluhan rasa nyeri.

Seluruh responden penelitian menjelaskan kualitas nyeri yang dirasakan berupa rasa panas seperti terbakar, berdenyut, kebas, dan rasa nyeri yang hebat. Kualitas nyeri kanker bersifat subjektif untuk setiap responden sehingga tidak dapat disamakan kualitas nyeri yang dirasakan masing-masing responden. Responden penelitian mendapatkan obat pereda nyeri (analgesik) yang diberikan maksimal dua kali dalam sehari, namun obat analgesik tersebut hanya dapat memberikan efek pereda nyeri selama 1-2 jam setelah pemberian obat termasuk dalam jenis opioid. Walsh (1997) dikutip oleh Yastati (2010) menyatakan semua golongan opioid menimbulkan efek analgesik dan efek lainnya melalui reseptor opiat di otak dan medulla spinalis. Analgesik tersebut memiliki banyak jenis, namun hanya sedikit yang terbukti memiliki nilai praktis dalam penanganan nyeri kronis.

Hasil penelitian ini juga menunjukkan bahwa $p=0,000$ yang berarti bahwa secara statistik dapat diartikan terdapat perbedaan yang bermakna antara skor kecemasan sebelum dan setelah intervensi. Kekhawatiran akan kondisi penyakit kanker yang diderita, pengobatan yang dijalani, efek dari pengobatan yang dijalani, belum siap menerima penyakit kanker yang diderita, kekhawatiran terhadap kondisi keluarga, keluhan yang dirasakan, belum siap menerima kematian merupakan stressor yang menimbulkan kecemasan pada responden penelitian.

Tingkat kecemasan dan intensitas nyeri mempunyai korelasi yang signifikan (Melzack \& Wall, 2006). Pengaruh intensitas nyeri terhadap kecemasan juga dapat dilihat dari teori gate control yaitu jika modulasi input melewati input nosisepsi, gerbang kemudian diblok dan transmisi nosisepsi berhenti atau dihalangi di substansia gelatinosa tanduk dorsal dari korda spinalis. Faktor perilaku dan emosional mempengaruhi gerbang melalui mekanisme menghambat transmisi impuls nyeri (Butar-Butar, Yustina, \& Harahap, 2015). Hambatan transmisi impuls nyeri juga dapat dimodulasi oleh adanya opiat endogen yang penting dalam sistem analgesik tubuh dengan cara menutup mekanisme pertahanan ini dengan merangsang sekresi endorphin yang akan menghambat pelepasan substansi P. Hasil penelitian ini menyatakan bahwa skor kecemasan mengalami penurunan bersamaan dengan penurunan terhadap skala nyeri. Orang yang cemas dan tegang akan membuka gerbang sehingga rangsang nyeri akan meningkat (Kaplan, Sadocks, \& Greb, 2007).

Perubahan intensitas nyeri yang dirasakan oleh responden selain karena pelepasan hormon endorphin juga disebabkan oleh distraksi yang mengarahkan responden harus berfokus pada setiap gerakan yang dilakukan sehingga dapat mengalihkan perhatian responden. Rasa nyaman mulai dirasakan pada gerakan ke-12 dan 13 dikarenakan pusat nyeri yang dirasakan berada pada bagian adomen (perut) sehingga peneliti menganjurkan untuk memperbanyak melakukan gerakan di daerah tersebut.

Latihan PMR bekerja melibatkan aktivitas sistem saraf otonom yaitu dengan meningkatkan kerja saraf parasimpatis dan menurunkan stimulasi sistem saraf simpatis serta hipotalamus sehingga pengaruh stres fisik terhadap keduanya menjadi minimal (Haryati, 2015). Aktivasi sistem saraf parasimpatis akan menurunkan denyut jantung, memperlambat laju pernafasan, meningkatkan aliran darah ke otot dan saluran pencernaan sehingga dapat mengurangi distress akibat gejala fisik (Ramadhani \& Putra, 2008). PMR akan mengontrol aktivitas kemudian stimulus tersebut akan mempengaruhi neurotransmitter (norephineprin, 
serotonin, GABA) yang mengatur perasaan dan pikiran seseorang. Penyampaian stimulus ke sistem saraf pusat tersebut menyebabkan terjadinya pelepasan endorphin yang menyebabkan ketegangan otot menjadi berkurang sehingga membuat tubuh menjadi relaks (Syarif \& Putra, 2014). Endorphin bekerja dengan mengikat reseptor opiat dan opiat endogen yang kemudian akan membentuk suatu sistem penekanan nyeri intrinsik. Ikatan tersebut dapat mengurangi nyeri dengan mencegah dibebaskan reseptor sebagai neurotransmitter penghasil nyeri.

PMR merupakan intervensi perilaku yang dapat mengurangi kecemasan. Teori ini didukung bahwa kecemasan dan relaksasi otot menghasilkan kondisi fisiologis yang berlawanan dan tidak dapat timbul bersama-sama. Respon neurologis terhadap kecemasan berupa ketegangan otot, maka ketegangan ini dapat dipulihkan dengan relaksasi otot dan kecemasan akan berkurang (Haryati, 2015).

Rasionalisasi penggunaan PMR untuk mengurangi kecemasan juga didukung oleh model stress-koping yang menyatakan bahwa individu berhadapan dengan stressor akan menimbulkan respon afektif dan fisiologis pada aktivitas neurologis, seperti peningkatan tekanan darah atau denyut jantung pada penilaian pertama. PMR dapat memberikan manfaat ganda yaitu menimbulkan adaptasi individu yang lebih positif dalam waktu yang singkat dan penurunan kecemasan yang tidak bergantung pada proses netralisir stressor (Haryati, 2015). PMR telah membantu pasien kanker serviks untuk meningkatkan relaksasi terhadap berbagai gejala dan keluhan yang dirasakan sehingga pasien lebih toleran terhadap berbagai aktivitas sehari-hari.

\section{KESIMPULAN}

1. Skala nyeri pasien kanker serviks sebelum dan setelah diberikan intervensi didapatkan rata-rata sebesar 5,75 dan 3,06. Skor kecemasan pasien kanker serviks sebelum dan setelah diberikan intervensi didapatkan rata-rata dan nilai tengah sebesar 49,88 dan 50(63-30) serta 31,31 dan 28(5423).

2. Hasil penelitian menyatakan terdapat perbedaan yang bermakna skala nyeri dan skor kecemasan sebelum dan setelah dilakukan intervensi PMR ( $p$-value $=0,000$ ).

3. Latihan PMR sebagai salah satu terapi non farmakologi terbukti dapat menurunkan nyeri dan kecemasan pada pasien kanker serviks.

\section{SARAN}

Hasil penelitian dapat menjadi bahan masukan bagi perawat dalam memberikan asuhan keperawatan maternitas khususnya memberikan edukasi mengenai terapi PMR dalam mengatasi nyeri dan kecemasan pada pasien kanker serviks. Peneliti selanjutnya dapat melakukan penelitian lebih lanjut khususnya pada responden dengan karakteristik yang sama dengan mempertimbangkan penggunaan kelompok kontrol sebagai pembanding yang kuat untuk penelitian serta menggunakan desain penelitian yang berbeda dengan tujuan untuk menggali pengalaman pasien dalam mengatasi nyeri dan kecemasan yang diakibatkan karena kanker serviks.

\section{DAFTAR PUSTAKA}

1. Aziz, F., Andrijono, Saifuddin., A.B. (2006). Onkologi Ginekologi : Buku Acuan Nasional. Jakarta: Bina Pustaka Sarwono Prawirohardjo.

2. Badan Penyelenggara Jaminan Kesehatan Nasional. (2016). Profil BPJS Kesehatan Nasional pada Pasien Kanker. (Online). Diakses di http://bpjs-kesehatan.go.id/ pada 15 November 2017.

3. Berek, J.S. (2012). Berek's \& Nova's Gynecology, Ed $15^{\text {th }}$. Philadelphia: Lippincott William \& Wilkins.

4. Butar-Butar, D., Yustina, I., Harahap, I.A. (2015). Hubungan Karakteristik Nyeri dengan Kecemasan pada Pasien Kanker Payudara yang Menjalani 
Kemoterapi di RSUD Dr. Pirngadi Medan. Idea Nursing Journal 1(1): 51-60.

5. Casey, A., Benson, H. (2012). Panduan Harvard Medical School:Menurunkan Tekanan Darah. Jakarta: PT Bhuana IImu Populer.

6. Dinas Kesehatan Provinsi Sumatera Selatan. (2015). Profil Kesehatan Provinsi Sumsel. (Online). Diakses di http://dinkes.sumselprov.go.id/ pada 15 November 2017.

7. Haryati, Sitorus, R. (2015). Pengaruh Latihan Progressive Muscle Relaxation Terhadap Status Fungsional dalam Konteks Asuhan Keperawatan Pasien Kanker dengan Kemoterapi di RS.dr.Wahidin Sudirohusodo Makassar. Jurnal Medula 2(2):167177.

8. Kaplan, H.I., Sadock, B.J., Grebb, J.A. (2010). Sinopsis Psikiatri Jilid 2. Jakarta: Binarupa Aksara.

9. Lasut, E., Rarung, M., Suparman, E. (2015). Karakteristik Penderita Kanker Serviks di BLU RSUP Prof. DR.R.D.Kandou. Jurnal e-Clinic 3(1): 83-86.

10. LeMone, P., Burke, K. (2008). Medical Surgical Nursing:Critical Thinking in Client Care Ed $4^{\text {th }}$. New Jersey: Pearson Prentice Hall.

11. Maryani, A. (2009). Pengaruh Progressive Muscle Relaxation Terhadap Kecemasan dan Mual Muntah Setelah Kemoterapi pada Pasien Kanker Payudara di RS.dr.Hasan Sadikin Bandung. Tesis. Jakarta: Program Pascasarjana Fakultas IImu Keperawatan Universitas Indonesia.

12. Melzack, R.., Wall, P.D. (2006). Pain Mechanisms : A New Theory. Science New Series Journal 150(36): 20-26.

13. Prandana, D.A., Rusda, M. (2013). Pasien Kanker Serviks di RSUP dr.H.Adam Malik Medan Tahun 2011. Jurnal Fakultas Kedokteran Universitas Sumatera Utara 1(2): 14.

14. Ramadhani, N., Putra, A.A. (2008). Pengembangan

Multimedia
Relaksasi. (Online). Diakses di http://staf.ugm.ac.id/relaksasi_otot.p df pada 30 Mei 2018.

15. Shute, C. (2013). The Challenges of Cancer Pain Assessment and Management. Ulster Medical Journal 82(1):40-42.

16. Susilowati, E., Sirait, A.M. (2014). Pengetahuan Tentang Faktor Risiko, Perilaku dan Deteksi Dini Kanker Serviks dengan Inspeksi Visual Asam Asetat (IVA) pada Wanita di Kecamatan Bogor Tengah Kota Bogor. Jurnal Peneliti Kesehatan 42(3):193-202.

17. Susilawati, D. (2013). Hubungan Dukungan Keluarga dengan Tingkat Kecemasan Penderita Kanker Serviks Paliatif di RSUP dr. Sardjito Yogyakarta. Jurnal Keperawatan Diponegoro 4(2):87-99. (Online). Diakses di http://ejournal.umm.ac.id pada 25 Mei 2018.

18. Suwiyoga, I.K. (2013). Penanganan Nyeri pada Kanker Serviks Stadium Lanjut. (Online). Jurnal Studi Jender Srikandi. Diakses di http://ojs.unud.ac.id/ pada 26 Oktober 2017.

19. Syarif, H., Putra, A. (2014). Pengaruh Progressive Muscle Relaxation Terhadap Penurunan Kecemasan pada Pasien Kanker yang Menjalani Kemoterapi : $A$ Randomized Clinical Trial. Idea Nursing Journal 5(3):1-8.

20. Wulandari, M.S.R.., Effendy, C., Nisman, W.A. (2017). Kualitas Hidup, Nyeri, dan Kecemasan pada Wanita Penderita Kanker Serviks dan Kanker Ovarium di RSUP Dr. Sardjito Yogyakarta: Studi Komparasi. Thesis. (Online). Diakses di http://etd.repository.ugm.ac.id pada 1 April 2018.

21. Yastati, S.C. (2010). Evaluasi Penggunaan Obat Anti Nyeri pada Pasien Kanker Serviks Rawat Inap di RSUP dr.Sardjito Yogyakarta Periode Januari-Juli 2009. Skripsi. Surakarta: Fakultas Farmasi Universitas Muhammadiyah Surakarta. 